\title{
KEUPAYAAN MENYELESAIKAN MASALAH MATEMATIK BERAYAT MENGGUNAKAN STRATEGI MELUKIS GAMBAR RAJAH DALAM KALANGAN MURID TAHUN 3 SEKOLAH RENDAH
}

\author{
${ }^{1}$ Norazlin binti Mohd Rusdin, ${ }^{2}$ Mohd Uzi bin Dollah \\ ${ }^{1,2}$ Fakulti Pembangunan Manusia \\ Universiti Pendidikan Sultan Idris \\ 35900 Tanjong Malim, Perak, Malaysia \\ *emel : uzi.dollah@fpm.upsi.edu.my
}

Received : 27 Oktober 2018; Accepted : 28 November 2018; Published : 29 Disember 2018

\begin{abstract}
Abstrak
Kajian ini dijalankan bertujuan untuk mengenal pasti keupayaan murid Tahun 3 sekolah rendah menyelesaikan masalah matematik berayat berdasarkan Model Penyelesaian Masalah Polya. Kajian ini merupakan kajian kualitatif dengan reka bentuk kajian kes. Pemilihan peserta kajian dilakukan secara persampelan bertujuan dan melibatkan seorang peserta Tahun 3 di sebuah sekolah kebangsaan di Daerah Kinta Utara. Peserta ini berada pada tahap penguasaan baik dalam matematik. Pengumpulan data menggunakan Teknik Think Aloud, Protokol Temu Bual dan Senarai Semak Pemerhatian. Dapatan kajian yang berbentuk rakaman video, skrip penulisan penyelesaian masalah dan catatan penyelidik dianalisis secara kualitatif melalui lima proses iaitu penerokaan data kajian, transkripsi, mengorganisasi, pengkodan dan analisis dapatan. Analisis menjelaskan proses penyelesaian masalah oleh murid merujuk kepada Model Polya, khususnya strategi melukis gambar rajah. Hasil kajian menunjukkan peserta telah melaksanakan proses memahami masalah, merancang dan melaksanakan strategi, menyemak semula penyelesaian serta menggunakan strategi melukis gambar rajah secara agak menyeluruh dan berkesan dalam menyelesaikan empat soalan matematik berayat yang dikemukakan. Kesimpulannya, peserta berupaya menyelesaikan masalah matematik berayat dengan melakukan keempat-empat langkah dalam model Polya. Implikasi kajian menunjukkan proses penyelesaian masalah berdasarkan 4 langkah Model Polya dan strategi melukis gambar rajah adalah sesuai dipratikkan dalam pengajaran dan pembelajaran penyelesaian masalah matematik berayat dalam kalangan murid Tahun 3 sekolah rendah.
\end{abstract}

Kata kunci Penyelesaian Masalah Matematik; Strategi Melukis

Gambar Rajah; Think Aloud.

\begin{abstract}
This study was aimed to identify the ability of Standard 3 primary school pupils in solving mathematical word problem based on Problem Solving Model by Polya. This study is a qualitative research with case study design. The selection of study participant was based on purposive sampling and involving one participant of Standard 3 pupil from a primary school in North Kinta District. The participant was at good performance in mathematics.
\end{abstract}




\begin{abstract}
Data collections were using Think Aloud technique, Interview Protocol and Observation Checklist. The findings in the form of video recordings, problemsolving written script and reseacher field notes were analyzed qualitatively through five processes namely study data exploratory, transcription, organizing, coding and analysis of findings. The analysis describes the process of problem-solving implemented by the pupil according to Problem Solving Model by Polya, specifically drawing a diagram strategy. The results showed that the participant performed the process of understanding the problem, devising and implementing the strategies, review the solution and use drawing a diagram strategies comprehensively and effectively in solving four mathematical word problems given. As a conclusions, the study found that the participant overally was able to solve mathematical word problem by doing the four steps of Problem Solving Model by Polya. The study shows the problem solving process based on a 4-step of Problem Solving Model by Polya and draw a diagram strategy is suitable for teaching and learning of mathematical word problem solving among the Standard 3 pupils of primary school.
\end{abstract}

Keywords $\quad$ Mathematical Problem Solving; Draw A Diagram Strategy; Think Aloud.

\title{
PENDAHULUAN
}

Kemahiran penyelesaian masalah sering dianggap sebagai salah satu aset terpenting yang perlu ada pada diri murid dalam usaha menjadikan mereka modal insan yang progresif dan mampu memenuhi kehendak serta cabaran masa depan (Roslina, T. Subahan \& Effandi, 2010). Matematik dan penyelesaian masalah berperanan luas dalam kehidupan seharian manusia. Melalui kemahiran penyelesaian masalah, murid dapat mengukuhkan pengetahuan dan membina pemahaman yang baru, mengaplikasikan dan menyesuaikan pengetahuan dan strategi, memantau dan membuat refleksi ke atas proses berfikir, menanamkan sifat ingin tahu, keyakinan, ketabahan, ketekunan dan kreatif (Norulbiah \& Effandi, 2016; Nekmahtul \& Masitah, 2015; Roslina, T. Subahan \& Effandi, 2010; Kilpatrick \& Swafford, 2001; NCTM, 2000). Penyelesaian masalah merupakan objektif dan fokus utama dalam pembelajaran matematik (Maslinah, 2016; Lai, 2007; Andy, 2003). Murid diharapkan dapat membina pengetahuan dan kemahiran baru melalui proses penyelesaian masalah, meyelesaikan masalah yang terdapat dalam kurikulum matematik serta mengaplikasikan pelbagai strategi menyelesaian masalah dalam konteks yang berbeza (Farizan, 2013; Lai, 2007).

Penyelesaian masalah matematik berayat memerlukan murid mahir dalam membaca soalan, mengenalpasti maklumat penting dalam masalah, memahami apa penyelesaian yang hendak dicari serta menjalankan proses pengiraan melibatkan operasi asas (Buku Teks Matematik Tahun 3, KPM, 2013). Berdasarkan model Polya (1957), proses penyelesaian masalah dipermudahkan dengan meleraikan maklumat dalam soalan. Peleraian maklumat dibuat melalui 4 langkah utama model Polya (1957) iaitu menterjemah/memahami masalah, merancang strategi penyelesaian, melaksanakan perancangan dan menyemak semula jawapan yang diperolehi (Esen, 2016; Maslinah, 2016; Norulbiah \& Effandi, 2016; Bruun, 2013; Farizan, 2013; Samsudin \& Fatimah, 
KEUPAYAAN MENYELESAIKAN MASALAH MATEMATIK BERAYAT MENGGUNAKAN STRATEGI MELUKIS GAMBAR RAJAH DALAM KALANGAN MURID TAHUN 3 SEKOLAH RENDAH

2004; Nekmahtul \& Masitah, 2015). Model Polya (1957) juga memerlukan murid berfikir tentang apa yang dicari, apa maklumat berguna yang diberi, operasi yang diperlukan untuk menyelesaikan masalah dan memastikan jawapan yang diperolehi adalah logik (Bruun, 2013).

Melukis gambar rajah merupakan salah satu strategi dalam visualisasi yang digunakan oleh murid dalam menyelesaikan masalah matematik berayat (Samsudin \& Fatimah, 2004; Apryl, Delinda \& Amy, 2015; Carmel, 1995) dan berjaya meningkatkan keupayaan penyelesaian masalah di kalangan murid (Maslinah, 2016; Bruun, 2013). Strategi melukis gambar rajah adalah berdasarkan visualisasi atau gambaran mental murid terhadap konsep atau masalah abstrak yang dikemukakan (Suzieleez \& Tajularipin, 2006; Maslinah, 2016). Strategi melukis gambar rajah membantu murid menterjemah kefahaman mereka terhadap sesuatu masalah matematik berayat kepada bentuk yang lebih mudah difahami (Maslinah, 2016; Rita \& Mulia, 2016; Apryl, Delinda \& Amy, 2015) dan mempercepatkan tugas mereka mendapatkan penyelesaian (Samsudin \& Fatimah, 2004). Kejayaan menyelesaikan masalah banyak dipengaruhi oleh keupayaan murid membina perwakilan masalah yang sesuai (Roslina, T. Subahan \& Effandi, 2010). Ini bermaksud gambar rajah yang dilukis berkesan dalam membantu murid menguasai penyelesaian masalah dengan lebih baik.

\section{KERANGKA KONSEPTUAL}

Kajian ini dijalankan dengan mendedahkan murid kepada kemahiran penyelesaian masalah matematik berayat yang lebih terancang dan sistematik berasaskan model Polya (1957) dan menggunakan strategi melukis gambar rajah sebagai strategi penyelesaian masalah.

Hubungan antara Proses Menyelesaikan Masalah Matematik Berayat dan Strategi Melukis Gambar Rajah, adalah seperti berikut:

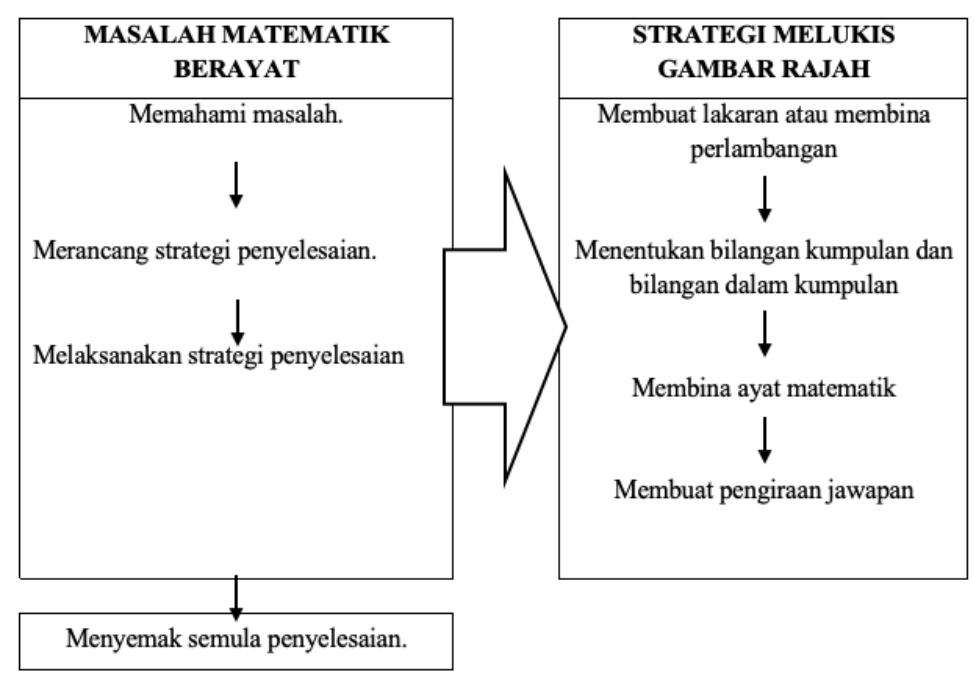

Rajah 1 Kerangka Konsep Menyelesaikan Masalah Matematik Berayat Menggunakan Strategi Melukis Gambar Rajah (Ubahsuai Model Polya, 1957) 
Proses penyelesaian masalah melibatkan empat langkah yang berkesinambungan dan berturutan untuk diikuti. Langkah pertama ialah memahami dan mentafsir masalah. Pada peringkat ini, murid akan membaca soalan dan biasanya dilakukan berulang kali sehingga murid dapat memahami maksud dan kehendak soalan, mengenal pasti nilainilai berangka yang terlibat serta mencari kata-kata kunci. Mengambil panduan yang dimuatkan dalam buku teks Matematik Tahun 3, murid akan menentukan "apa yang diberi" dan "apa yang dicari”.

Langkah kedua ialah merancang strategi. Pada langkah ini murid mula menggunakan strategi melukis gambar rajah di mana murid akan membina gambaran visual yang sesuai bagi setiap maklmuat dan nilai berangka yang telah dikenalpasti sebelum dihubungkan dengan kata-kata kunci dalam minda. Gambaran visual ini kemudiannya dipindahkan kepada lukisan gambar rajah pada kertas. Gambar rajah yang telah dilukis dengan lengkap dan mengambil kira semua maklumat yang diperlukan akan memudahkan murid menentukan operasi yang hendak digunakan.

Dalam langkah ketiga iaitu melaksanakan strategi penyelesaian, murid membina ayat matematik dengan operasi yang sesuai berdasarkan lukisan gambar rajah dalam langkah sebelum ini. Murid akan memindahkan ayat matematik ke bentuk lazim atau strategi pengiraan yang lain seperti lattice, sigai dan sebagainya untuk mendapatkan penyelesaian bagi masalah yang dikemukakan.

Langkah terakhir ialah langkah keempat iaitu menyemak semula penyelesaian. Murid boleh menyemak semula penyelesaian dengan menggunakan operasi lain yang mempunyai perkaitan dari segi konsep seperti menyemak penyelesaian operasi darab dengan menggunakan penambahan berulang atau operasi bahagi.

\section{OBJEKTIF KAJIAN}

Kemahiran proses menyelesaikan masalah yang baik dan berkesan dalam pembelajaran matematik perlu dikuasai oleh murid pada peringkat awal lagi. Kajian ini bertujuan untuk mengenal pasti keupayaan murid menggunakan strategi melukis gambar rajah dalam proses penyelesaian masalah berasaskan empat langkah dalam model Polya (1957).

Objektif kajian ini ialah

i. mengenal pasti keupayaan murid Tahun 3 memahami masalah matematik berayat.

ii. mengenal pasti keupayaan murid Tahun 3 merancang strategi dalam menyelesaikan masalah matematik berayat.

iii. mengenal pasti keupayaan murid Tahun 3 melaksanakan strategi dalam menyelesaikan masalah matematik berayat.

iv. mengenal pasti keupayaan murid Tahun 3 menyemak semula penyelesaian dalam menyelesaikan masalah matematik berayat.

\section{METODOLOGI KAJIAN}

Kajian ini merupakan suatu kajian kualitatif yang menggunakan reka bentuk kajian kes. Kajian kes ini dijalankan ke atas seorang peserta yang dipilih dari kalangan murid Tahun 3. Peserta ini mempunyai tahap pencapaian sederhana dalam penguasaan 
KEUPAYAAN MENYELESAIKAN MASALAH MATEMATIK BERAYAT MENGGUNAKAN STRATEGI MELUKIS GAMBAR RAJAH DALAM KALANGAN MURID TAHUN 3 SEKOLAH RENDAH

Matematik. Peserta ini diberi kod P1. Peserta dinilai melalui dua kaedah iaitu pertama, analisis rakaman penyelesaian masalah menggunakan teknik think aloud bersamasama skrip jawapan penyelesaian masalah matematik berayat yang ditulis oleh peserta dan disusuli dengan rakaman temu bual berserta dengan senarai semak.

Teknik think aloud ialah teknik yang memerlukan peserta membaca masalah dengan kuat dan menyuarakan buah fikiran mereka sepanjang proses menyelesaikan masalah termasuklah menyatakan secara lisan setiap apa yang difikirkan dan dilakukan (Nekmahtul \& Masitah, 2015). Think aloud digunakan bertujuan untuk memupuk pemikiran kefahaman yang lebih baik di kalangan murid (Whimbey \& Lochhead, 1999) dan mendedah serta mengembangkan proses-proses kognitif yang berkait rapat dengan proses penyelesaian masalah (Larkin et al, 1984; Kotsopoulus, 2010). Teknik think aloud juga membantu murid belajar dengan cara menyedari proses berfikir yang digunakan dalam menyelesaikan masalah matematik.

\section{PENGUMPULAN DATA}

Penyelesaian masalah matematik berayat ini mengandungi 6 soalan. Keenam-enam soalan ini merupakan soalan rutin tetapi mempunyai aras kesukaran yang berbeza iaitu mudah, sederhana dan sukar. Item pada aras mudah terdiri daripada pernyataan langsung, tidak ada maklumat pengganggu dan perlukan satu langkah penyelesaian sahaja. Soalan aras sederhana ditulis dalam bentuk pernyataan tidak langsung. Manakala soalan aras sukar bersifat pernyataan tidak langsung dan memerlukan dua langkah penyelesaian. Soalan-soalan yang dimuatkan adalah seperti berikut:

i. Soalan 1 (S1): Penyelesaian masalah darab berayat melibatkan nombor bulat.

Aras mudah: pernyataan langsung dan perlukan 1 langkah penyelesaian sahaja Pak Iman mempunyai 3 reban burung puyuh. Setiap reban memuatkan 335 ekor burung puyuh. Kira jumlah burung puyuh Pak Iman?

ii. Soalan 2 (S2): Penyelesaian masalah darab berayat melibatkan panjang Aras mudah: pernyataan langsung dan perlukan 1 langkah penyelesaian sahaja. Setiap hari, Haikal berulang-alik sejauh $524 \mathrm{~m}$ dari rumahnya ke sekolah. Berapakah jarak yang dilaluinya dalam masa 5 hari?

iii. Soalan 3 (S3): Penyelesaian masalah darab berayat melibatkan jisim.

Aras mudah: pernyataan langsung dan perlukan 1 langkah penyelesaian sahaja. Jisim sepeket gula perang ialah $650 \mathrm{~g}$. Jisim seguni beras pula 8 kali ganda jisim gula perang. Berapakah jisim seguni beras?

iv. Soalan 4 (S4): Penyelesaian masalah darab berayat melibatkan wang Aras sederhana: Penyataan tidak langsung dan memerlukan 1 langkah penyelesaian sahaja.

Harga tiket masuk ke Taman Animasi ialah RM129 seorang. Berapakah jumlah wang yang mesti dibayar oleh Rizqeen dan 5 orang rakannya? 
v. Soalan 5 (S5): Penyelesaian masalah darab berayat melibatkan masa dan waktu. Aras sederhana: pernyataan tidak langsung, memerlukan 2 langkah penyelesaian. Maira berkumpul bersama-sama 3 orang rakan dan 2 orang sepupunya. Setiap daripada mereka memiliki 195 keping setem. Hitung jumlah setem mereka.

vi. Soalan 6 (S6): Penyelesaian masalah darab berayat melibatkan isipadu cecair Aras sukar: pernyataan tak langsung dan memerlukan 2 langkah penyelesaian. Bunyamin minum 500me susu setiap hari. Berapakah isi padu susu yang diminum oleh Bunyamin dalam masa seminggu dalam liter dan mililiter?

Peserta menyelesaikan keenam-enam masalah di atas dalam dua sesi penyelesaian masalah yang diadakan secara berasingan dengan tujuan mengekalkan tumpuan peserta. Pada setiap sesi, peserta menyelesaikan 3 soalan menggunakan teknik think aloud. Proses penyelesaian masalah yang dilaksanakan telah dirakam. 30 minit selepas setiap sesi penyelesaian masalah selesai, suatu sesi temu bual dijalankan berpandukan senarai semak yang disediakan. Temu bual ini diadakan bagi mendapatkan penjelasan daripada peserta untuk perkara-perkara yang kurang jelas semasa proses penyelesaian masalah menggunakan teknik think aloud dijalankan.

\section{DAPATAN KAJIAN}

Dapatan daripada penyelesaian masalah secara think aloud disusuli dengan temubual menunjukkan peserta mempunyai keupayaan yang baik dalam menyelesaikan masalah menggunakan 4 langkah model Polya (1957) dan strategi melukis gambar rajah.

i. Memahami masalah (MM)

P1 berupaya memahami keenam-enam masalah yang dikemukakan. P1 mampu mengenal pasti maklumat-maklumat penting, perkaitan antara maklumatmaklumat dan kehendak soalan. Dalam temu bual selepas penyelesaian masalah S3, P1 menjelaskan "Saya faham maksud 8 kali ganda. Jisim 1 guni beras sama dengan jisim 8 peket gula. Jadi, jisim gula darab 8, dapat jisim seguni beras".

P1 menjelmakan maklumat-maklumat yang diberi dalam bentuk gambar rajah dengan tepat seperti dalam Rajah 2.

Contohnya, Dalam S3, P1 dapat memahami konsep 8 kali ganda. P1 melukis gambar 8 peket gula perang yang bersamaan dengan seguni beras (P1/S3/MM1) seperti yang ditunjukkan dalam Rajah 1.

Dalam S5 pula, P1 tahu bahawa bilangan orang yang terlibat ialah 6 orang iaitu termasuk Maira dan tidak mengambil nilai berangka yang terdapat pada soalan semata-mata (P1/S5/MM2). P1 melukis gambar rajah dengan tepat seperti dalam Rajah 3. 
KEUPAYAAN MENYELESAIKAN MASALAH MATEMATIK BERAYAT MENGGUNAKAN STRATEGI MELUKIS GAMBAR RAJAH DALAM KALANGAN MURID TAHUN 3 SEKOLAH RENDAH

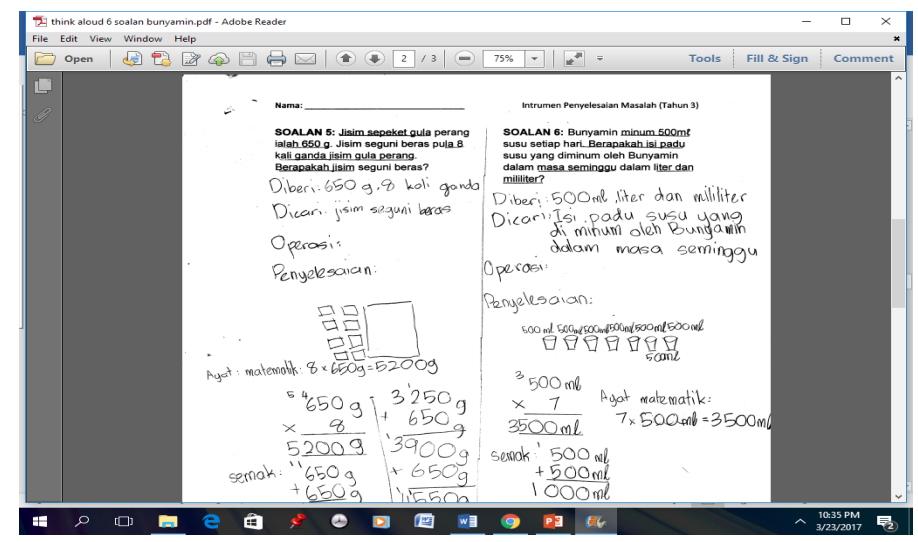

Rajah 2 Memahami Masalah Soalan 3 (P1/S3/MM1)

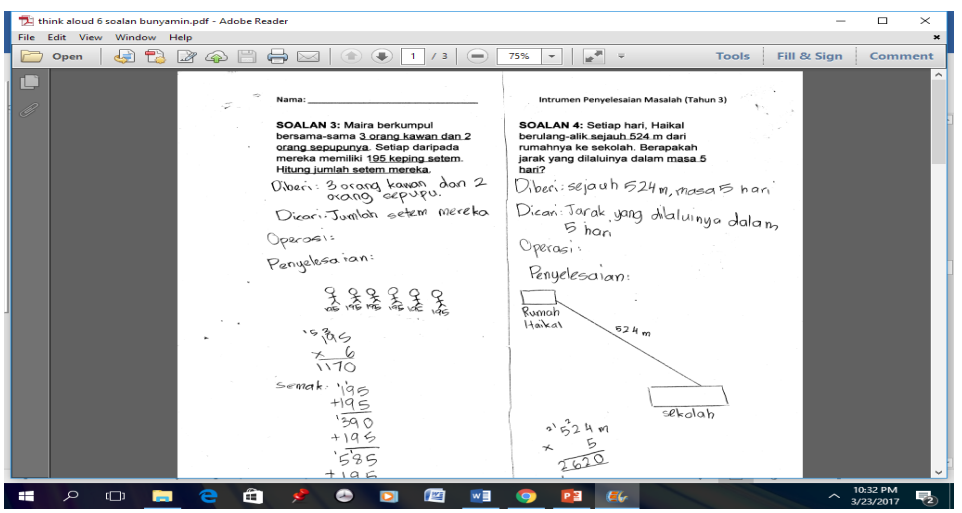

Rajah 3 Memahami Masalah Soalan 5 (P1/S5/MM2)

ii. Merancang strategi (RS)

P1 menunjukkan kemampuan merancang strategi iaitu menentukan operasi dan nilai-nilai berangka yang perlu dilibatkan dalam pengiraan berpandukan gambar rajah yang dilukis. Semasa sesi temu bual, P1 memberitahu, "Kalau nombor yang sama diulang-ulang, ini kena darab".

Misalnya, dalam S2, peserta dapat mengaitkan jarak Haikal berulang-alik sejauh $524 \mathrm{~m}$ selama 5 hari dengan operasi darab dan menulis 5 x 524 (P1 tertinggal unit $\mathrm{m}$ pada ayat matematik yang dibina) (P1/S2/RS1). Rujuk Rajah 4.

Manakala dalam S6, P1 tahu menukarkan perkataan seminggu dalam soalan kepada 7 hari. Daripada 7 gelas susu dengan isi padu sebanyak 500m $\ell$ setiap satunya, P1 tahu bahawa operasi yang terlibat ialah darab dan menulis $7 \mathrm{x}$ $500 \mathrm{~m} \ell$. P1 mengaitkan pengulangan nilai berangka dengan operasi darab (P1/ S6/RS2) seperti dalam Rajah 5. 


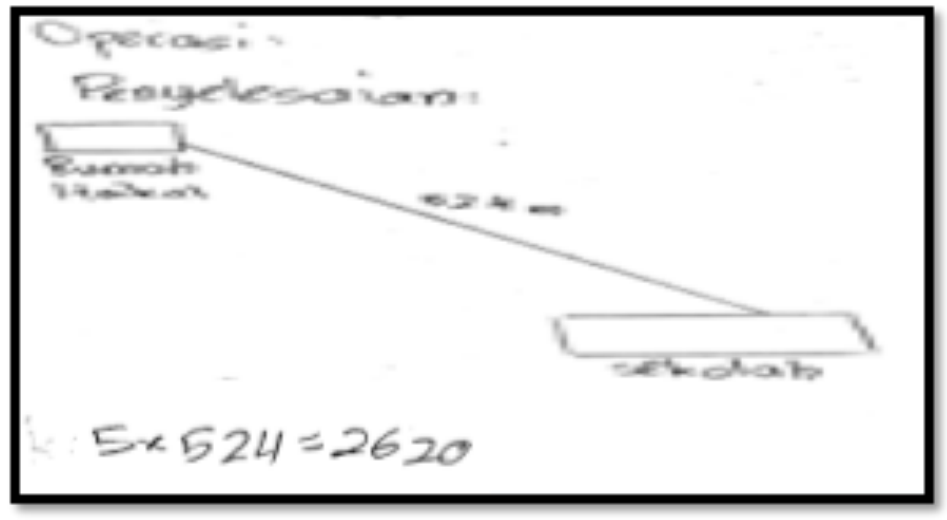

Rajah 4 Merancang Strategi Soalan 2 (P1/S2/RS1)

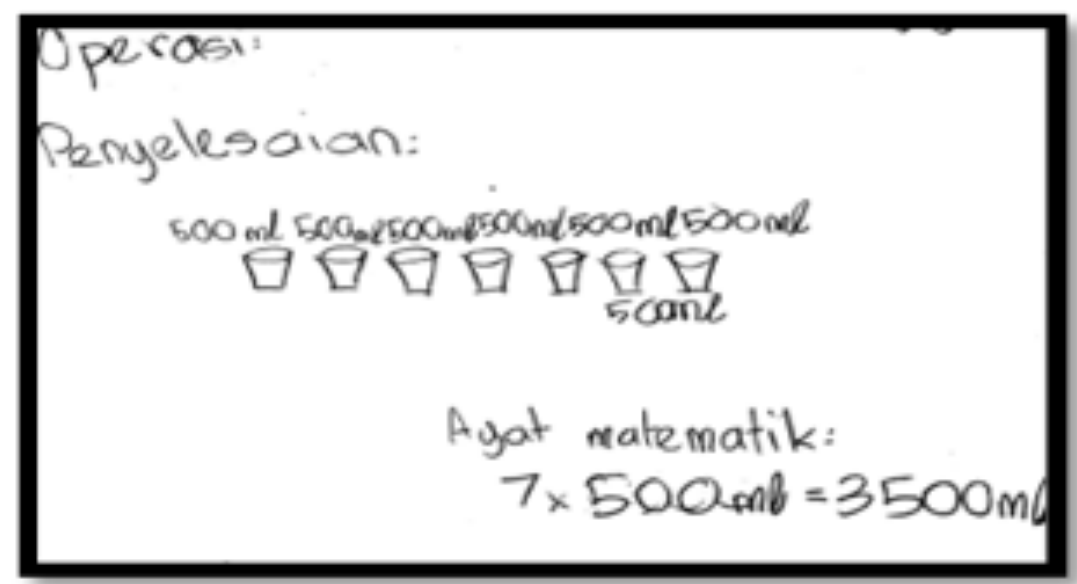

Rajah 5 Merancang Strategi Soalan 6 (P1/S6/RS2)

iii. Melaksanakan strategi (LS)

P1 telah melaksanakan strategi iaitu melakukan pengiraan yang menjana penyelesaian dengan tepat bagi keenam-enam soalan. Perlaksanaan strategi ini adalah berdasarkan strategi yang telah dirancang dalam langkah kedua di mana ayat matematik dipindahkan ke bentuk lazim dan pengiraan dilakukan. Ketika ditemu bual, P1 berkata, "Saya perlu darab untuk dapatkan jawapan. Saya darab guna bentuk lazim biasa".

Contohnya, dalam S1, P1 telah mendarabkan 335 dengan 3 untuk mendapatkan jumlah burung puyuh yang dikehendaki iaitu 1005 ekor ((P1/S1/LS1). Dalam S4 pula, P1 mendarabkan 129 dengan 6 untuk mendapatkan jumlah wang yang perlu dibayar untuk masuk ke taman animasi iaitu 774. P1 mengakui terlupa meletakkan unit RM pada nilainilai wang yang berkenaan (P1/S4/LS2) 


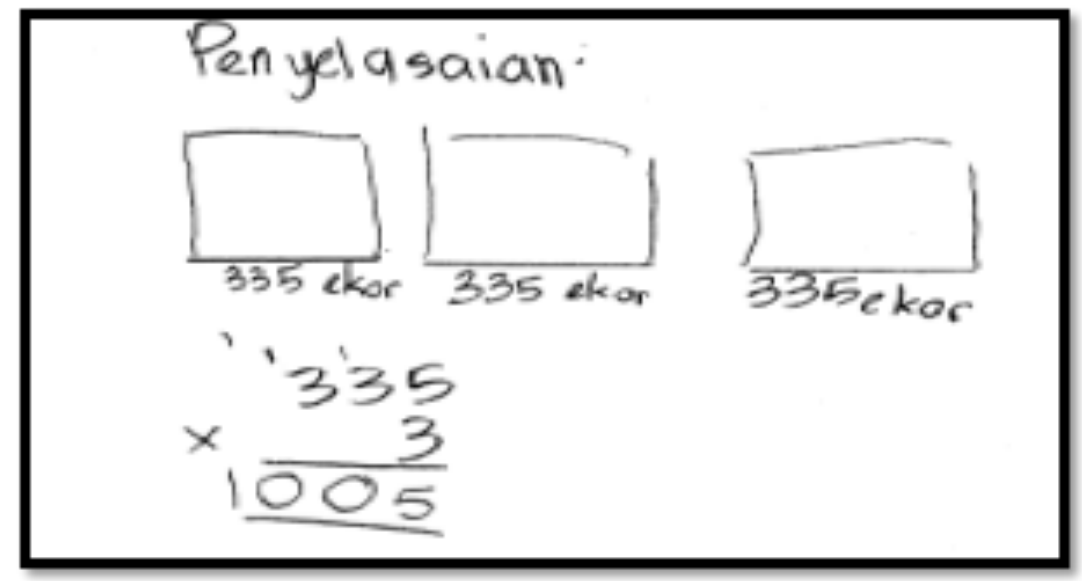

Rajah 6 Melaksanakan Strategi Soalan 1 (P1/S1/LS1)

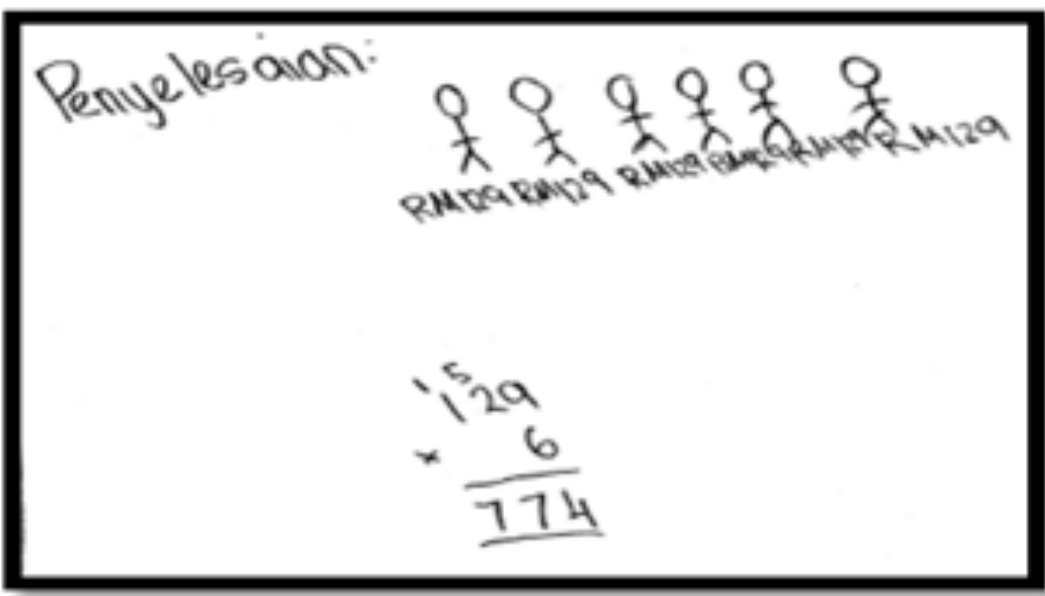

Rajah 7 Melaksanakan Strategi Soalan 4 (P1/S4/LS2)

iv. Menyemak semula penyelesaian (SP)

P1 telah melakukan semak semula untuk memastikan jawapan yang diperolehi adalah tepat. P1 mendapati persamaan pada nilai semak semula dengan jawapan yang diperolehi bagi kesemua 6 soalan. Dalam sesi temu bual, P1 menjelaskan "Saya kena semak semula. Nak pastikan jawapan yang kira tadi betul ke tak. Saya guna tambah berulang”. Contohcontoh di bawah diambil daripada langkah menyemak semula yang dilaksanakan oleh P1 untuk S2 dan S5. 


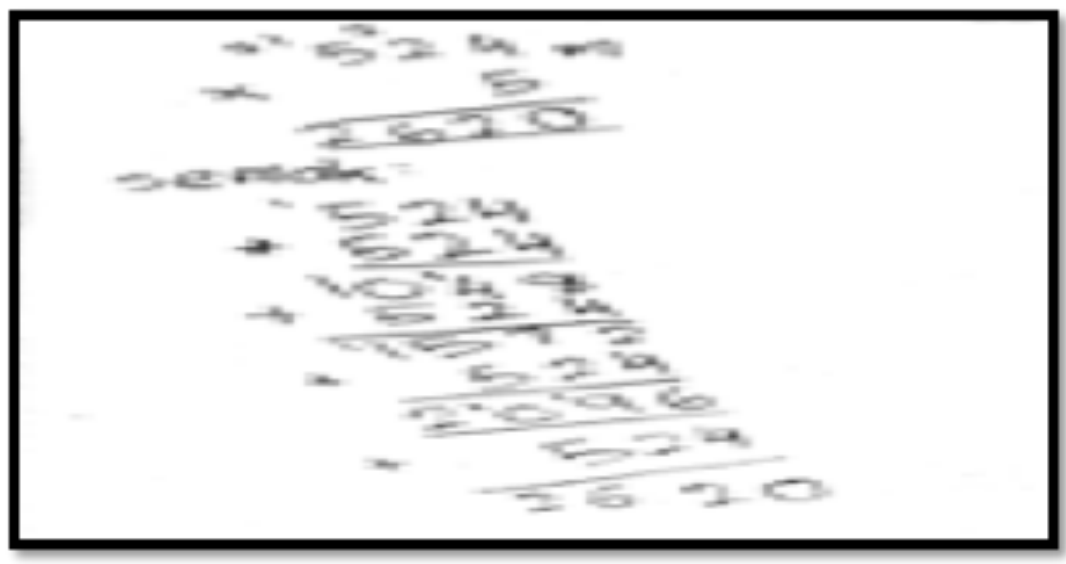

Rajah 8 Menyemak Semula Soalan 2 (P1/S2/PS1)

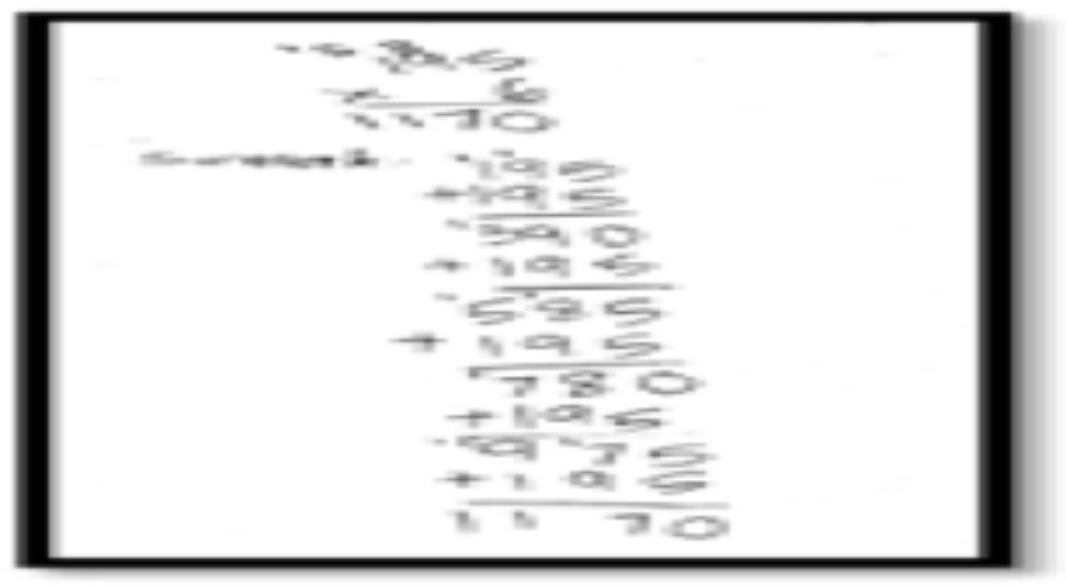

Rajah 9 Menyemak Semula Soalan 5(P1/S5/PS2)

Dapatan kajian menunjukkan murid Tahun 3 mempunyai keupayaan yang baik dalam melaksanakan proses penyelesaian masalah berdasarkan empat langkah yang terkandung dalam model Polya (1957) iaitu memahami masalah, merancang strategi, melaksanakan strategi dan menyemak semula. Murid Tahun 3 juga berupaya menggunakan strategi melukis gambar rajah untuk penyelesaian masalah matematik yang berkesan dan tepat.

\section{PERBINCANGAN}

Keupayaan murid Tahun 3 menyelesaikan masalah matematik berayat berdasarkan 4 langkah dalam model Polya (1957) dan menggunakan strategi melukis gambar rajah dapat dikenal pasti dalam kajian ini. Peserta kajian menunjukkan keupayaan yang baik dalam memahami soalan penyelesaian masalah, merancang strategi penyelesaian, melaksanakan strategi penyelesaian dan menyemak semula jawapan yang diperolehi bagi memastikan ketepatannya. Keberkesanan model Polya (1957) sebagai asas proses penyelesaian masalah telah dilaporkan dalam kajian-kajian yang dijalankan oleh Farizan (2013) dan Shenglan Yuan (2013). Model Polya (1957) berupaya membantu murid meningkatkan kemahiran mereka menyelesaikan masalah matematik berayat (Farizan, 2013). Keempatempat langkah penyelesaian masalah dalam model Polya (1957) membolehkan murid 
KEUPAYAAN MENYELESAIKAN MASALAH MATEMATIK BERAYAT MENGGUNAKAN STRATEGI MELUKIS GAMBAR RAJAH DALAM KALANGAN MURID TAHUN 3 SEKOLAH RENDAH

menyedari sifat semula jadi matematik dan penyelesaian masalah matematik berayat (Shenglan Yuan, 2013).

Strategi melukis gambar rajah telah digunakan secara berkesan oleh peserta terutamanya semasa merancang strategi iaitu dalam menentukan operasi yang hendak digunakan. Lukisan gambar rajah telah memudahkan peserta melihat pengulangan nilai berangka dalam soalan dan mengaitkannnya dengan operasi darab. Dapatan ini selari dengan hasil kajian yang telah dilaporkan sebelum ini yang menyatakan strategi melukis gambar rajah berkesan dan praktikal digunakan dalam penyelesaian masalah matematik (Samsudin Drahman, 2004; Lau, 2007; Bruun, 2013; Delinda \& Amy, 2014; Esen, 2016).

Peserta telah menyelesaikan keenam-enam masalah dengan tepat. Sedikit kelemahan yang dapat dikesan ialah peserta terlupa untuk menulis unit bagi dua soalan yang melibatkan unit $m$ dan RM. Kelemahan seperti ini dikategori sebagai cuai. Kecuaian dalam penyelesaian masalah sering dilaporkan dalam kajian-kajian yang telah dijalankan oleh banyak penyelidik. Andy Peter (2003) melaporkan kecuaian merupakan kesilapan kedua terbanyak yang dilakukan oleh murid manakala Tuan Siti Humaira (2016) pula menyatakan kecuaian sebagai kesilapan terbesar yang dilakukan oleh muridnya dalam penyelesaian masalah matematik berayat. Penekanan perlu diberikan terhadap penulisan unit pada setiap penyelesaian masalah yang dilakukan. Isu kecuaian ini boleh diatasi dengan melakukan semak semula secara menyeluruh. Semak semula tidak seharusnya bertumpu pada menyemak penyelesaian semata-mata. Perkara-perkata penting lain seperti penulisan unit pada jawapan juga perlu dititikberatkan.

\section{KESIMPULAN DAN CADANGAN}

Model Polya (1957) merupakan model penyelesaian masalah yang ideal untuk dipratikkan oleh murid Tahun 3 khususnya dan murid sekolah rendah umumnya berdasarkan keberkesanannya yang telah terbukti dalam banyak kajian. Guru-guru perlu mengambil inisiatif untuk menerap malah melatih murid-murid menyelesaikan masalah dengan menggunakan empat langkah dalam model Polya (1957) iaitu memahami masalah, merancang strategi, melaksanakan strategi dan menyemak semula. Model Polya (1957) dapat membimbing murid menyelesaikan masalah matematik berayat dengan lebih sistematik, terancang dan penuh kesedaran terhadap proses penyelesaian yang sedang dilaksanakan. Langkah menyemak semula dapat memahirkan murid membuat hubungkait antara operasi-operasi asas yang terlibat kerana murid menggunakan operasi yang berbeza semasa penyelesaian dan semak semula.

Murid Tahun 3 sedang dalam peralihan peringkat perkembangan pembelajaran matematik dari peringkat ikonik ke peringkat simbolik berdasarkan teori pembelajaran Bruner (1964). Strategi melukis gambar rajah merupakan strategi yang sesuai bagi murid Tahun 3 gunakan dalam penyelesaian masalah matematik berayat. Strategi melukis gambar rajah berkesan dalam membantu murid memahami masalah, merancang strategi penyelesaian dan melaksanakan strategi penyelesaian yang tepat. Gambar rajah yang dilukis dapat menterjemahkan masalah dalam bentuk ayat ke bentuk yang lebih mudah difahami serta membolehkan murid menentukan operasi asas yang tepat untuk digunakan dalam penyelesaian. Pemilihan operasi asas yang tepat untuk menghubungkan maklumat-maklumat penting dalam soalan memudahkan perlaksanaan strategi penyelesaian yang betul.

Ramai guru tahu tentang model Polya (1957) dan strategi melukis gambar rajah. Namun begitu, hanya segelintir sahaja yang menerapkannya dalam pengajaran dan pembelajaran penyelesaian masalah matematik berayat. Dengan mengambil kira keupayaan murid menggunakan model Polya (1957) dan strategi melukis gambar rajah secara berkesan seperti yang dinyatakan dalam laporan ini, guru-guru matematik dicadangkan menjadikan kedua-duanya sebagai elemen utama dalam setiap pengajaran dan pembelajaran penyelesaian masalah matematik berayat yang dilaksanakan. 


\section{RUJUKAN}

Bruun, F. (2013). Elementary Teachers' Perspectives of Mathematics Problem Solving Strategies. The Mathematics Educator, Vol. 23, No. 1, 45-59.

Ersoy, E. (2016). Problem Solving and Its Teaching in Mathematics. The Online Journal of New Horizons in Education, Vol. 6, Issue 2.

Farizan Ismail. (2013). Keberkesanan Kaedah Model Bar Dalam Menyelesaikan Masalah Matematik Berayat. Tesis Sarjana. Universiti Teknologi Malaysia.

G. Polya. (1957). How to Solve It: A New Aspect of Mathematical Method. Second Edition, Princeton University Press. New Jersey.

Killpatrick, J., Swafford, J. \& Findell, B. (2001). Adding It Up: Helping Children Learn Mathematics. NRC ISBN: 0-309-50524-0

Leong, L. K. (2007). Penyelesaian Masalah Matematik Sekolah Rendah dengan Menggunakan Strategi Melukis Gambar Rajah. Pembudayaan Penyelidikan Ke Arah Kecemerlangan Profesionalisme Keguruan. Seminar Penyelidikan Pendidikan Institut Perguruan Batu Lintang Tahun 2007.

Maslinah Lasiun. (2016). Keberkesanan Kaedah Visualisasi: Meningkatkan Keupayaan Menyelesaikan Masalah Matematik Berayat. Proceeding of ICECRS, 1 (2016), 1-11, ISSN. 2548-6160.

Nekmahtul Hafizah Abdul Kani \& Masitah Shahril. (2015). Applying the Thinking Aloud Pair Problem Solving Strategy in Mathematics Lesson. Asian Journal of Management Sciences \& Education, Vol. 4, No. 2, 20-28.

Norulbiah Ngah \& Effandi Zakaria. (2016). Keupayaan Pelajar Dalam Menjana Masalah, Menyelesaikan Masalah Matematik dan Sikap Pelajar Terhadap Penyelesaian Masalah. Jurnal Pendidikan Matematik, Vol.4, No. 1, 1-16.

Peter, A. (2003). Pola Kesilapan Murid Tahun Tiga Wira Menyelesaikan Masalah Bercerita Dalam Matematik: Satu Kajian Tindakan. Retrieved on September 23, 2016, form http:// www.ipbl.edu.my/portal/penyelidikan/jurnalpapers/jurnal2003/2003_andy.pdf

Poch, A. L., van Garderen, D. \& Scheuermann, A. (2015). Student's Understanding of Diagram for Solving Word Problem: A Framework for Assessing Diagram Proficiency. Teaching Exceptional Children, Vol. 47, No. 3, 153-162.

Polya, G. (1973). How to solve it. Princeton: Princeton University Press.

Qin, Z., Johnson, D. W. \& Johnson, R. T. (1995). Cooperative Versus Competitive Efforts and Problem Solving. Review of Educational Research Summer 1995, Vol. 65, No. 2, 129-143.

Rita Novita \& Mulia Putra. (2016). Using Task Like PISA'S Problem to Support Student's Creativity in Mathematics. Journal on Mathematics Education, Vol. 7, No. 1, 31-42.

Roslina Radzali, T. Subahan Mohd Meerah \& Effandi Zakaria. (2010). Hubungan antara Kepercayaan Matematik, Metakognisi dan Perwakilan Masalah dengan Kejayaan Penyelesaian Masalah Matematik. Jurnal Pendidikan Malaysia 35(2) (2010): 1-7.

Samsudin Drahman \& Fatimah Saleh, (2004). Visualisation in Solving Mathematics Word Problem. Jurnal Pendidik dan Pendidikan, 19, 47-65.

Suzieleez Syrene Abdul Rahim \& Tajularipin Sulaiman. (2006). Gambaran Mental dan Perwakilan Pelajar Lepasan Sijil Pelajaran Malaysia Tentang Konsep Fungsi. Jurnal Teknologi, 44(E) Jun 2006: 45-60 (C) Universiti Teknologi Malaysia.

Tuan Siti Humaira Tuan Hashim \& Mohamad Amir Shah Ahmad. (2016). Analisis Kesalahan Newman dalam Penyelesaian Masalah Matematik Tahun 3. Jurnal Pendidikan Sains \& Matematik Malaysia VOL.6 NO.2 / ISSN 2232-0393 69, 69-84.

Van Garderen, D. \& Scheuermann, A. (2014). Diagramming Words Problems. Intervention in School and Clinic. doi:1177/1053451214560889.

Yuan, S. (2013). Incorporating Polya's Problem Solving Method in Remedial Math. Journal of Humanistic Mathematics, Vol. 3, No.1, 96-107. 